\title{
Prednisone-dependent asthma: inflammatory indices in induced sputum
}

\author{
M.M.M. Pizzichini, E. Pizzichini, L. Clelland, A. Efthimiadis, I. Pavord, J. Dolovich, F.E. Hargreave
}

Prednisone-dependent asthma: inflammatory indices in induced sputum. M.M.M. Pizzichini, E. Pizzichini, L. Clelland, A. Efthimiadis, I. Pavord, J. Dolovich, F.E. Hargreave. (C) ERS Journals Ltd 1999 .

ABSTRACT: The kinetics of changes in inflammatory indices in induced sputum from eight prednisone dependent asthmatics whose minimum clinical maintenance and exacerbation doses were known were investigated.

The study began on the last day of a course of $30 \mathrm{mg}$ prednisone daily for one week. Thereafter, the daily prednisone was reduced in a structured way to below the maintenance dose. This treatment was continued until a clinical exacerbation occurred. Prednisone $30 \mathrm{mg}$ daily was then given again for one week.

The mean duration of prednisone reduction was 7.4 weeks and the median dose was $7.5 \mathrm{mg}^{-\mathrm{day}^{-1}}$. Increases in sputum eosinophils preceded increases in blood eosinophils by 4 weeks and worsening of symptoms and forced expiratory volume in one second by 6 weeks. The clinical exacerbation was also accompanied by sputum neutrophilia and increases in sputum eosinophil cationic protein (ECP), fibrinogen and interleukin (IL)-5. Treatment with prednisone suppressed median sputum eosinophilia (from 16.3 to $0 \%, p<0.001$ ), decreased sputum ECP (from 7,480 to $700 \mu \mathrm{g} \cdot \mathrm{L}^{-1}, \mathrm{p}=0.01$ ), but did not improve neutrophil numbers, fibrinogen or IL-5.

The results show that the reduction of prednisone treatment in prednisonedependent asthmatics evokes a severe airway eosinophilic inflammatory response. Clinical and blood indices deteriorate later than those in sputum suggesting that sputum examination may be useful to identify the minimum regular dose of prednisone required in these patients.

Eur Respir J 1999; 13: 15-21.
Asthma Research Group, Depts of Medicine and Paediatrics, St Joseph's Hospital and McMaster University, Hamilton, Ontario, Canada.

Correspondence: F.E. Hargreave, Firestone Regional Chest and Allergy Unit, St Joseph's Hospital, 50 Charlton Avenue East, Hamilton, Ontario, Canada L8N 4A6.

Fax: 9055216037

Keywords: Airway inflammation prednisone-dependent asthma severe asthma sputum cell counts

sputum fluid-phase measurements sputum induction

Received: December 191997

Accepted after revision July 281998

Supported by a grant from the Asthma Society of Canada. M. Pizzichini and E. Pizzichini were Visiting Professors at McMaster University, supported by a fellowship from Boehringer Ingelheim (Canada) Ltd.
Airway inflammation in asthma includes infiltration of inflammatory cells $[1,2]$, secretion of pro-inflammatory cell products and cytokines [3], increased microvascular permeability with exudation of plasma and secretion of mucus [4]. It is considered to be the cause of asthma and an important determinant of exacerbations and disease severity. Glucocorticoids are the most effective therapy for suppressing airway inflammation $[5,6]$.

Factors that may influence the magnitude of response to glucocorticoid treatment include the presence of eosinophilic airway inflammation [7], the severity of the inflammation and the state of glucocorticoid receptor affinity [8]. Most asthmatics respond to small doses of steroid given by inhalation. A few asthmatics need prednisone daily to control symptoms and airflow limitation. They are regarded as having more severe airway inflammation and variable airflow limitation, but this association has not been examined in any detail [9].

Studying airway inflammation and its response to treatment in more severe asthma has been difficult because the methods used to assess airway inflammation directly have been too invasive. Current research has introduced indu-

For editorial comments see page 5. ced sputum as a relatively noninvasive, reliable, valid [3] and responsive [6] technique to measure airway inflammation. It can be applied in more severe asthma situations and be used repeatedly to investigate the effects of treatment.

In a previous study, induced sputum was used to examine indices of airway inflammation in patients with a severe exacerbation of asthma who were not on regular treatment with prednisone to follow the kinetics of the response to treatment with prednisone [6]. The sputum characteristics were a pronounced cell degeneration, increased numbers of eosinophils with many free eosinophil granules, and increased levels of eosinophil cationic protein (ECP), interleukin (IL)-5 and fibrinogen. Treatment with prednisone improved the forced expiratory volume in one second (FEV1) and decreased blood eosinophils and serum ECP levels within 1 day, while the sputum indices fell more slowly, between 2-7 days.

In the present study, the characteristics of the sputum inflammatory response were examined in patients with prednisone-dependent asthma before and after treatment of an exacerbation of their asthma caused by a structured reduction of prednisone treatment. The kinetics of changes in clinical features in relation to changes in sputum and blood inflammatory indices during the reduction of prednisone were also followed. 


\section{Methods}

\section{Subjects}

Nine adults were consecutively recruited from the Firestone Regional Chest and Allergy Clinic to confirm and treat prednisone-dependent asthma. One patient was not prednisone-dependent and is reported elsewhere [10]. The remaining eight entered the study. The diagnosis of asthma was established by symptoms of episodic wheeze, chest tightness and/or dyspnoea and by a $>12 \%$ variability in FEV1, mean 18.5\% (range 13-27\%) (table 1). All patients had needed daily or repeated courses of prednisone for a mean of 4.8 yrs (range 2-10 yrs) and had side-effects from its use including osteoporosis (all subjects), diabetes (3/8 patients) and cataracts $(3 / 8)$. Without prednisone all pati-ents had daily symptoms which disturbed sleep. All but one had previous hospital admissions. All patients were investigated by standard procedures to exclude or minimize the following confounders or exacerbating factors: noncompliance, inadequate inhaler technique, exposure to common allergens or occupational sensitizers that could be avoided, sinusitis, major nasal polyps (detected in one patient with surgical correction), the use of concomitant drugs that may affect the response to asthma treatment, acetylsalicylic acid intolerance (in three patients, who avoided nonsteroidal anti-inflammatory drugs), gastroesophageal reflux (in four, all treated), bronchiectasis, sleep disturbance disorder, recurrent bronchial infections, and vocal cord dysfunction. None had radiological evidence of other chest disease or respiratory infection and none had received antibiotics within 1 month of, or during, the study period. The study was approved by the hospital research committee and all patients gave written informed consent.

\section{Study design and procedure}

There was an initial selection period with a mean \pm SD of $15.6 \pm 4.2$ months during which the presence of asthma was objectively confirmed, possible confounders were identified and the minimum dose of prednisone required to prevent an exacerbation for 6 months was determined. The patients were also on regular treatment with high-dose inhaled steroid and the potential effects of possible confounders were minimized. During this period, there were three trials of prednisone reduction in six patients, two trials in one and a single trial in one patient.

The formal study was prospective, descriptive and before and after intervention. It began on the last day of a course of $30 \mathrm{mg}$ prednisone daily (50 $\mathrm{mg}$ in one subject) for 1 week. Then, in six patients, the daily prednisone dose was reduced in a structured way by $5 \mathrm{mg}$ every 2 weeks to 5-10 $\mathrm{mg}$ below the maintenance dose which had previously been unable to prevent an asthma exacerbation. In the other two patients it was reduced to this dose more quickly. This dose was maintained until a clinical exacerbation occurred. Patients were then restored to the same high dose of prednisone at the start of the study for 1 week.

The patients were seen on the last day of the first highdose prednisone treatment, on the day of reduction of each dose of prednisone, at the time of the clinical exacerbation and after 1 week of high-dose prednisone, in the early afternoon. At the first visit, the patient characteristics were documented, spirometry was performed and sputum and blood were collected for inflammatory indices. Patients began a diary of symptoms, medication use and morning prebronchodilator and postbronchodilator peak expiratory flow (PEF). The patients were instructed to contact the study physician immediately if there was a deterioration in their asthma symptoms or PEF. At subsequent visits spirometry was performed, sputum and blood were obtained and daily diaries were collected.

The definition of an asthma exacerbation was established before starting the study as an objective deterioration in the postbronchodilator FEV $1 \geq 20 \%$ and/or morning PEF $\geq 30 \%$. If there was an asymptomatic deterioration in the FEV1 $\geq 20 \%$ but $<30 \%$, the patient was maintained on the same dose of prednisone until there was an increase in symptoms score of at least 4 points higher than the score at the start of the study, an increased need for short-acting $\beta_{2}$ agonists of $\geq 4$ puffs. day $^{-1}$ or a further fall in FEV1.

Table 1. - Patient characteristics

\begin{tabular}{|c|c|c|c|c|c|c|c|c|c|c|c|c|c|}
\hline \multirow{3}{*}{$\begin{array}{l}\text { Sub- } \\
\text { ject } \\
\text { No. }\end{array}$} & \multirow{3}{*}{$\begin{array}{l}\text { Age } \\
\text { yrs } \\
(\text { Sex })\end{array}$} & \multirow{3}{*}{$\begin{array}{c}\text { Duration } \\
\text { yrs }\end{array}$} & \multirow{3}{*}{$\begin{array}{c}\text { FEV1 L }(\%) \\
\Delta \text { after BD* }\end{array}$} & \multirow{3}{*}{$\begin{array}{c}\mathrm{PC} 20 \\
\mathrm{mg} \cdot \mathrm{mL}^{-1}\end{array}$} & \multirow[b]{3}{*}{ Atopy } & \multirow{3}{*}{$\begin{array}{c}\mathrm{IgE} \\
\mathrm{U} \cdot \mathrm{mL}^{-1}\end{array}$} & \multicolumn{7}{|c|}{ Characteristics on daily minimum treatment } \\
\hline & & & & & & & \multirow{2}{*}{$\begin{array}{l}\text { Symptom } \\
\text { score }^{*}\end{array}$} & \multirow{2}{*}{$\begin{array}{c}\text { PEF } \\
\text { L }\end{array}$} & \multirow{2}{*}{$\begin{array}{c}\text { FEV1 } \\
\text { L }\end{array}$} & \multicolumn{4}{|c|}{ Treatment } \\
\hline & & & & & & & & & & Pred & Bud & Salb & Salm \\
\hline 1 & $65(\mathrm{~F})$ & 8 & $0.3(13)$ & 6.5 & $\mathrm{~N}$ & 231 & 0 & 450 & $2.1(91)$ & 15 & 6400 & 0 & 0 \\
\hline 2 & $33(\mathrm{~F})$ & 2 & $0.8(27)$ & $<0.03$ & $\mathrm{~N}^{\dagger}$ & 56 & 7 & 330 & $3.1(103)$ & 17.5 & 3200 & 200 & 100 \\
\hline 3 & $50(\mathrm{M})$ & 20 & $0.6(18)$ & $<0.03$ & $\mathrm{~N}$ & 427 & 2 & 335 & $2.9(88)$ & 10 & 3200 & 0 & 100 \\
\hline 4 & $56(\mathrm{M})$ & 11 & 0.7 (19) & 0.8 & $\mathrm{Y}^{\dagger}$ & 688 & 4 & 570 & $3.2(89)$ & 15 & 3200 & 0 & 50 \\
\hline 5 & $60(\mathrm{~F})$ & 10 & $0.3(13)$ & ND & $\mathrm{Y}^{\dagger}$ & 57 & 10 & 220 & $1.5(65)$ & 20 & 3200 & 600 & $0^{\#}$ \\
\hline 6 & $59(\mathrm{~F})$ & 18 & 0.3 (14) & $\mathrm{ND}$ & $\mathrm{Y}$ & 32 & 0 & 400 & $1.5(65)$ & 15 & 3200 & 0 & 50 \\
\hline 7 & $56(\mathrm{~F})$ & 4 & $1.0(25)$ & 1.2 & $\mathrm{~N}$ & 372 & 0 & 460 & $3.3(83)$ & 10 & 2400 & 0 & 0 \\
\hline 8 & $55(\mathrm{M})$ & 2 & 0.8 (19) & 2.5 & $\mathrm{~N}$ & 10 & 0 & 550 & $3.7(86)$ & 10 & 1200 & 0 & 100 \\
\hline
\end{tabular}

F: female; M: male; Duration: duration of asthma symptoms; *: best improvement in forced expiratory volume in one second (FEV1) after $200 \mu \mathrm{g}$ inhaled salbutamol (\% increase); BD: bronchodilator; PC20: provocative concentration of methacholine causing a $20 \%$ fall in FEV1; ND: not done; Atopy: one or more positive allergy skin-prick tests; ${ }^{\dagger}$ : acetylsalicylic acid intolerance; IgE: serum immunoglobulin $\mathrm{E}$ (normal upper limit $<120 \mathrm{U} \cdot \mathrm{mL}^{-1}$ ); : scale ranged from 0 (asymptomatic) to 16 (most severe discomfort); PEF: peak expiratory flow (morning values); FEV1: postbronchodilator values; Pred: prednisone (mg.day $\left.{ }^{-1}\right)$; Bud: budesonide $\left(\mu \mathrm{g} \cdot \mathrm{day}^{-1}\right)$; Salb: salbutamol $\left(\mu \mathrm{g} \cdot \mathrm{day}^{-1}\right)$; Salm: salmeterol $\left(\mu \mathrm{g} \cdot \mathrm{day}^{-1}\right){ }^{*}$ : theophylline $\left(600 \mathrm{mg} \cdot \mathrm{day}^{-1}\right)+$ ipatropium $\left(120 \mathrm{mg} \cdot \mathrm{day}^{-1}\right)$. Subject no. 2,4 and 6 were exsmokers; subject no. 2 was the same as subject no. 4 in Ref. [6]. 
The study outcomes were sputum total cell count, cell viability, eosinophils and neutrophils, and blood eosinophils at each visit, and sputum fluid-phase ECP, fibrinogen and IL-5, and serum ECP only before and after the treatment of the exacerbation. Sputum and blood were examined blind to the clinical details.

\section{Clinical methods}

Patient characteristics were documented by questionnaire. Daily symptoms of wheeze, chest tightness, dyspnoea, and cough were recorded using a Likert scale, with each symptom ranging from 0 (absent) to 4 (most severe). Morning bronchodilator PEF was measured with a miniWright peak flow meter (Clement-Clarke International, London, UK) before and after bronchodilator and the best of three measurements was recorded. Medications were recorded as the number of actuations of each inhaler and the number of tablets of prednisone or theophylline. Inhaled short-acting $\beta_{2}$-agonist was recorded only if required as rescue medication. Spirometry was performed with a Collins water spirometer (Warren E, Collins Inc, MA, USA). Baseline measurements of slow vital capacity (VC) and FEV1 were taken according to American Thoracic Society (ATS) criteria [11] and reference values were taken from CRAPO et al. [12]. The response to inhaled salbutamol $200 \mu \mathrm{g}$ was measured as the percentage increase in FEV1. Methacholine inhalation tests were carried out by the method described by JUNIPER et al. [13] and the results were expressed as the provocative concentration causing a fall in FEV1 of $20 \%\left(\mathrm{PC}_{20}\right)$ in noncumulative units. Allergy skin tests were performed using the modified prick technique [14] with 19 common allergen extracts.

\section{Sputum induction}

Sputum was induced by the inhalation of an aerosol of saline [15] with modifications to improve its safety [6]. In brief, sputum was induced by inhalation of an aerosol of normal saline followed by hypertonic saline (3, 4 and 5\%) generated by a Fisoneb(B) ultrasonic nebulizer (Canadian Medical Products, Markham, Ontario, Canada) with an output of $0.87 \mathrm{~mL} \cdot \mathrm{min}^{-1}$ and particle size of $5.58 \mu \mathrm{m}$ aero-dynamic mass median diameter. The aerosol was inhaled for 1 or 2 min according to the severity of airflow limit-ation and the FEV1 was measured. The patients were asked to blow the nose, rinse the mouth and swallow the water to minimize contamination with postnasal drip and saliva. They were instructed to cough sputum into a sterile con-tainer whenever they felt that sputum might be present. These procedures were repeated for up to a total of 6 or $7 \mathrm{~min}$ of inhalation sequentially with each concentration until a sputum sample was obtained or a fall in the $\mathrm{FEV} 1 \geq 10 \%$ occurred.

\section{Sputum and blood examination}

The appearance of the sputum was recorded (mucoid, mucopurulent or purulent). Sputum selected from the expectorate was processed within $2 \mathrm{~h}$, as described by
Pizzichini et al. [3]. In brief, sputum was treated by adding a volume $(\mathrm{mL})$ of $0.1 \%$ dithiothreitol (DTT) (Sputalysin $10 \%$, Calbiochem, San Diego, CA, USA) equal to four times the weight (mg) followed by the addition of the same four volumes of Dulbecco phosphate-buffered saline (D-PBS). The suspension was filtered through a $48-\mu \mathrm{m}$ nylon gauze (BBSH Thompson, Scarborough, Ontario, Canada) and the total cell count of leukocytes and cell viability were determined. The filtrate was centrifuged at $790 \times g(3,000 \mathrm{rpm})$ for $4 \mathrm{~min}$ and the superpernatant was aspirated and stored in Eppendorf tubes at $-70^{\circ} \mathrm{C}$. The cell suspension was adjusted to $1.0 \times 10^{6} \cdot \mathrm{mL}^{-1}$ and cytocentrifuge preparations were made using $75 \mu \mathrm{L}$ of the cell suspension (Shandon III cytocentrifuge; Shandon Southern Instruments, Sewickley, PA, USA). One slide was air dried and stained by the Wright method. Four-hundred nonsquamous cells were counted and the results were expressed as a percentage of the total nonsquamous cell count. The concentration of ECP $\left(\mu \mathrm{g} \cdot \mathrm{L}^{-1}\right)$ in the thawed supernatant was determinated using a sensitive radioimmunoassay (RIA; Kabi Pharmacia Diagnostics AB, Uppsala, Sweden). Fibrinogen was measured by a sandwich enzyme-linked immunosorbent assay (ELISA) using a rabbit anti-human fibrinogen antibody (Dako A080; Dako, High Wycombe, UK). IL-5 (pg. $\mathrm{mL}^{-1}$ ) was measured by quantitative sand-wich enzyme immunoassay (Quantikine $^{\mathrm{TM}}$; R\&D Systems, Minneapolis, MN, USA).

The limits of detection for the fluid-phase ECP, fibrinogen and IL-5 were $2.0 \mu \mathrm{g} \cdot \mathrm{L}^{-1}, 0.79 \mu \mathrm{g} \cdot \mathrm{L}^{-1}$ and $7.8 \mathrm{pg} \cdot \mathrm{mL}^{-1}$ respectively. Venous blood was collected into a Vacutainer K3 EDTA (Becton Dickinson Vacutainer Systems, Franklin Lakes, NJ, USA) and a differential white cell count was obtained using Coulter STKS (Coulter Corp., Hialeah, FL, USA). The repeatability of fluid-phase ECP, fibrinogen and IL-5, calculated by the intraclass correlation coefficient in two measurements performed on two separate occasions in stable asthmatics, was high $(0.85,0.86$ and 0.69 , respectively) [3]. The assay used to measure serum ECP was the same as that described for sputum.

\section{Data analysis}

Results are reported as median and interquartile range (IQR) unless otherwise specified. All statistical tests were two-sided. Significance was accepted at $p<0.05$. Dependent variables with a non-normal distribution were logtransformed before analysis. The symptom score at each visit was calculated as the mean of the previous 3 days' average of the scores for each individual symptom. Paired t-tests were used for comparisons of clinical and inflammatory outcomes before and after treatment of the exacerbation. The time course of changes in symptoms score, use of rescue medication, FEV1, morning PEF and sputum and blood eosinophils, after prednisone reduction, was analysed by repeated measures analysis of variance (ANOVA) and the source of significant variation was identified by the Student-Newman-Keuls procedure to adjust the significance for multiple comparisons [16]. For this analysis sputum and blood eosinophils were considered increased if they were, respectively, two (3.4\%) and 1.5times $\left(0.6 \times 10^{6} \cdot \mathrm{L}^{-1}\right)$ higher than the highest values found in normal subjects in a previous study [17]. 

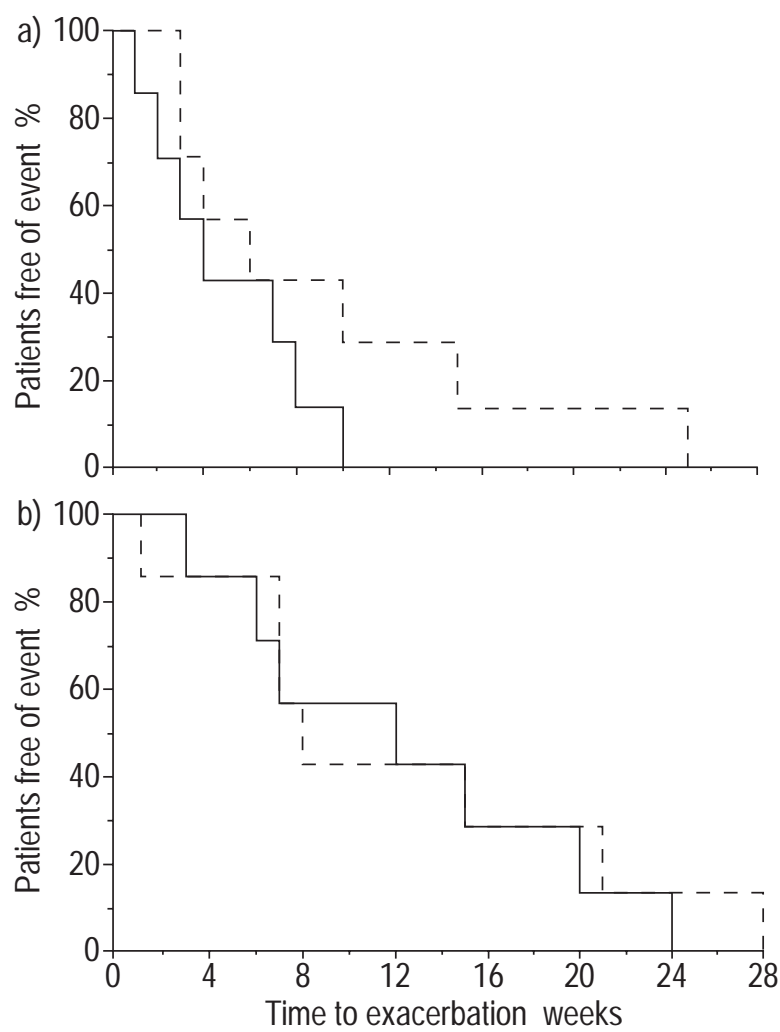

Fig. 1. - Time course of effects of the prednisone reduction on a) sputum $(-)$ and peripheral blood eosinophils $(---)$; and $b)$ forced expiratory volume in one second $(-)$ and symptoms score $(---)$.

\section{Results}

\section{Kinetics of effects of prednisone reduction}

Prednisone was reduced to the exacerbation dose over a mean \pm SD of $7.4 \pm 2.8$ weeks and this dose was maintained for $8.3 \pm 6.6$ weeks before a clinical exacerbation of predetermined severity occurred. Significant increases in sputum eosinophils occurred at a mean of 4.4 weeks (range 1.0-10.0) and preceded significant changes in symptoms, postbronchodilator FEV1 and blood eosinophils, which occurred at $11.2(1.0-27) 12.7(4.0-25.7)$ and $9.8(3.0-$ 25.7) weeks (all $\mathrm{p}=0.03$ ) (fig. 1 , table 2 ).

\section{Clinical and inflammatory characteristics at the exacerba- tion}

At the exacerbation the symptoms score increased by a mean $(95 \%$ confidence interval $(\mathrm{CI}))$ of $4.6(0.7-9.8)(\mathrm{p}=$
$0.01)$ and the $\beta_{2}$-agonists use by $400(100-800) \mu \mathrm{g}(\mathrm{p}=$ $0.01)$ (table 3$)$. The postbronchodilator PEF fell by 15.5 $(4.5-35.5) \%(\mathrm{p}=0.02)$ and the postbronchodilator FEV1 by $32.5(27.3-37.7) \%(\mathrm{p}<0.001)$. All patients produced mucoid sputum with good cell viability (63 (31)\%). The airway inflammatory process at the exacerbation (table 3 ) was characterized by eosinophilia, neutrophilia and marked increases in ECP and fibrinogen levels. Sputum IL-5 was only measurable in five subjects. In contrast, peripheral blood showed only modest increases in eosinophils and ECP and serum IL-5 was measurable in only one subject.

\section{Effects of treatment on clinical and inflammatory indices}

Treatment with higher doses of prednisone for 1 week significantly improved the clinical parameters of all subjects, except for patient 5 who received prednisone $50 \mathrm{mg}$ daily and had only a mild improvement in symptoms and morning PEF, but not in short-acting $\beta_{2}$-agonist use or postbronchodilator FEV1 (table 4). The mean (95\% CI) change after prednisone treatment in symptoms score was $-3.4(-1.2-5.7)(\mathrm{p}=0.008)$, in $\beta_{2}$-agonists use was -300 $(-100$ to -450$) \mu \mathrm{g}(\mathrm{p}=0.008)$, in PEF was 95.6 (31.5 to $159.7) \mathrm{L}(\mathrm{p}=0.01)$ and in postbronchodilator FEV1 was $0.80(0.43$ to 1.2$) \mathrm{L}(\mathrm{p}<0.001)$. Treatment with prednisone significantly suppressed sputum eosinophilia (from 16.3 (32.3) to $0(0.7) \%, \mathrm{p}<0.001)$, decreased sputum ECP (from $7,480(5,240)$ to $\left.700(784) \mu \mathrm{g} \cdot \mathrm{L}^{-1}, \mathrm{p}=0.01\right)$ and partially decreased fibrinogen (from $10,600(61,280)$ to 7,600 $(19,290) \mu \mathrm{g} \cdot \mathrm{L}^{-1}, \mathrm{p}=0.1$ ) and IL-5 (from 66.5 (150) to 44.1 (86) $\left.\mathrm{pg} \cdot \mathrm{mL}^{-1}, \mathrm{p}=0.3\right)$, but did not change neutrophils (from 57.6 (41.3) to $54.0(42.8) \%, \mathrm{p}>0.5)$ (table 4, fig. 2). The changes in blood eosinophils and ECP were in the same direction but quantitatively smaller than those in sputum, from $0.5(0.7)$ to $0.1(0.1) \times 10^{6} \cdot \mathrm{mL}^{-1}(\mathrm{p}=0.03)$ and from $33.0(38.5)$ to $10.8(7.2) \mu \mathrm{g} \cdot \mathrm{L}^{-1}(\mathrm{p}=0.01)$, respectively. These changes in inflammatory markers were confirmed by measuring the same markers before and after prednisone treatment in seven of the subjects during at least one other exacerbation during the prestudy period.

\section{Safety of sputum induction}

The safety and characteristics of sputum inductions were examined during the exacerbation and 1 week after treatment. Sputum was produced spontaneously on four occasions (three at the exacerbation visit and the other 1 week after treatment) and induced in 12 occasions. Normal or hypertonic saline $3 \%$ was used in all but one patient, who required a full sputum induction on both occasions. The

Table 2. - Kinetics of effects of prednisone reduction on clinical (mean \pm SD) and inflammatory indices (median (interquartile range)) at different time points

\begin{tabular}{lccc}
\hline & Study day 1 & At last prednisone treatment & At exacerbation \\
\hline Prednisone dose $\mathrm{mg}^{+}$ & $30(30-50)$ & $7.5(0-15)$ & $7.5(0-15)$ \\
Symptom score & $2.9(5.5)$ & $3.3(3.1)$ & $6.5(5.2)^{*}$ \\
FEV $\%$ & $83(11)$ & $73(12)$ & $55(0.7)^{* * *}$ \\
Blood eosinophils $\times 10^{6} \cdot \mathrm{L}^{-1}$ & $0.1(0.2)$ & $0.5(0.5)$ & $0.5(0.7)$ \\
Sputum eosinophils \% & $0(0.5)$ & $10.5(48)^{*}$ & $16.3(32.3)$ \\
Sputum neutrophils \% & $59.2(30.7)$ & $52.5(40.7)$ & $57.6(41.3)$ \\
\hline
\end{tabular}

Study day 1: 1 week after high-dose prednisone treatment. ${ }^{+}$: Median (minimum-maximum). FEV1: forced expiratory volume in one second. $\mathrm{p}$-Values are in relation to the previous treatment. $*: \mathrm{p} \leq 0.05 ; * * * \mathrm{p} \leq 0.001$. 
Table 3. - Patient characteristics at exacerbation

\begin{tabular}{|c|c|c|c|c|c|c|c|c|c|c|c|c|c|c|c|c|}
\hline \multirow[b]{2}{*}{$\begin{array}{l}\text { Subj. } \\
\text { No. }\end{array}$} & \multicolumn{5}{|c|}{ Clinical parameters } & \multicolumn{3}{|c|}{ Blood } & \multicolumn{8}{|c|}{ Sputum } \\
\hline & $\begin{array}{c}\text { Symp. } \\
\text { score }\end{array}$ & $\begin{array}{c}\text { PEF } \\
\text { L }\end{array}$ & $\begin{array}{l}\text { FEV1 } \\
\text { L (\%) }\end{array}$ & $\begin{array}{l}\text { Pred } \\
\text { mg. } \\
\text { day }^{-1}\end{array}$ & $\begin{array}{l}\text { Salb } \\
\mu \mathrm{g} \cdot \\
\text { day }^{-1}\end{array}$ & $\begin{array}{c}\mathrm{E} \\
\times 10^{6} \\
\mathrm{~L}^{-1}\end{array}$ & $\begin{array}{c}\text { ECP } \\
\mu \mathrm{g} \cdot \\
\mathrm{L}^{-1}\end{array}$ & $\begin{array}{l}\text { IL-5 } \\
\mathrm{pg} \cdot \\
\mathrm{mL}^{-1}\end{array}$ & $\begin{array}{c}\text { TCC } \\
\times 10^{6} \\
\mathrm{~mL}^{-1}\end{array}$ & $\begin{array}{l}\mathrm{E} \\
\%\end{array}$ & $\begin{array}{l}\mathrm{N} \\
\%\end{array}$ & $\begin{array}{l}\mathrm{L} \\
\%\end{array}$ & $\begin{array}{l}\mathrm{M} \\
\%\end{array}$ & $\begin{array}{l}\text { ECP } \\
\mu \mathrm{g} \cdot \\
\mathrm{L}^{-1}\end{array}$ & $\begin{array}{c}\mathrm{F} \\
\underset{\mathrm{L}}{\mathrm{L}} \cdot \\
\mathrm{L}^{-1}\end{array}$ & $\begin{array}{c}\text { IL-5 } \\
\mathrm{pg} \cdot \\
\mathrm{mL}^{-1}\end{array}$ \\
\hline 1 & 4 & 325 & $1.4(61)$ & 10 & 200 & 0.1 & 10 & UL & 6.2 & 41.4 & 43.4 & 0 & 14.2 & 25600 & 7520 & 80 \\
\hline 2 & 15 & 350 & $1.8(60)$ & 0 & 1000 & 1.7 & 54 & UL & 5.7 & 40.0 & 31.2 & 0.5 & 28.3 & 1360 & 9100 & 688 \\
\hline 3 & 4 & 330 & $2.0(61)$ & 0 & 400 & 0.9 & 53 & UL & 4.8 & 78.3 & 14.8 & 0 & 7.0 & 7360 & 11200 & 144 \\
\hline 4 & 8 & 320 & $2.3(64)$ & 10 & 800 & 0.4 & 36 & UL & 3.6 & 8.7 & 62.7 & 1.0 & 27.0 & 6720 & 10000 & UL \\
\hline 5 & 12 & 180 & $1.1(48)$ & 15 & 800 & 0.0 & 12 & UL & 9.9 & 20.5 & 52.5 & 0 & 27.0 & 6720 & 10000 & UL \\
\hline 6 & 8 & 340 & $1.0(45)$ & 10 & 1000 & 0.1 & 45 & 110 & 54.9 & 9.0 & 79.0 & 0 & 12.0 & 7760 & 88000 & 152 \\
\hline 7 & 1 & 260 & $2.1(53)$ & 5 & 0 & 0.5 & 30 & UL & 5.8 & 4.0 & 78.5 & 0 & 16.5 & 7600 & 136000 & UL \\
\hline 8 & 0 & 260 & $2.3(54)$ & 0 & 200 & 0.5 & 14 & - & 3.0 & 12.0 & 69.2 & 0.3 & 18.5 & 672 & 4960 & UL \\
\hline
\end{tabular}

Subj.: subject; Symp.: symptom; PEF: peak expiratory flow; FEV1: forced expiratory volume in one second; Pred: prednisone; Salb: salbutamol; E: eosinophils; ECP: eosinophil cationic protein; IL-5: interleukin-5; TCC: total cell count; N: neutrophils; L: lymphocytes; M: macrophages; F: fibrinogen; UL: under the limit of detection of the assay.

mean duration of induction was $9.5 \mathrm{~min}$. The FEV1 after sputum induction fell by a mean of 7.0 (range $0-19.5$ )\%.

\section{Discussion}

The results indicate that the prednisone-dependent asthmatics enrolled in this study developed eosinophilic bronchitis defined cytologically as a sputum eosinophilia of $>2 \%$ [17], when their prednisone dose was reduced. This feature preceded the increase in symptoms, deterioration in FEV1 and increase in peripheral blood eosinophils. The eosinophilic bronchitis, at the time of the clinical exacerbation, was accompanied by a marked increase in eosinophil activation (as measured by sputum ECP) and possibly by airway microvascular leakage (as measured by sputum fibrinogen). There was only a modest increase in sputum IL5. Treatment with higher doses of prednisone improved the clinical parameters, suppressed the eosinophilic bronchitis and decreased eosinophil activation. However, there was no parallel improvement in fibrinogen or IL-5 levels, at least after 1 week. The results suggest that prednisone-dependent asthma is associated with eosinophilic bronchitis which needs prednisone to suppress it. The failure to suppress IL-5 raises the possibility that other chemokines or cytokines are more important in the mechanisms of suppression of the eosinophilia in prednisone-dependent asthma.

This is the first study in subjects with prednisonedependent asthma using sputum induction to monitor the characteristics of the inflammatory response during alter- ations in prednisone treatment. The results cannot be considered biased by the design or methods. The subjects were enrolled consecutively during the investigation of whether or not they were prednisone dependent. Of the nine subjects studied in this way, one was found not to need prednisone, was therefore not enrolled in this study and was reported elsewhere [10]. The need for prednisone was determined in the remaining eight subjects during the initial selection period by a failure to reduce the dose of prednisone below a certain minimum maintenance dose which kept them well for at least 6 months. Then, during the study, the inception point followed a course of additional prednisone for 1 week and the definition of an objective exacerbation of asthma was appropriately predetermined. This strategy of including criteria of randomized controlled trials (RCT) in the design has been shown to give results which are almost identical to those obtained in RCT [18]. All of the laboratory measurements were made blind to the patients' characteristics. Finally, the method used for sputum examination had been shown to give reliable [3], valid and responsive $[6,19]$ results for the measurements made in the study.

Sputum eosinophilia was not present after treatment with a high dose of prednisone at the start of the study. Following prednisone reduction, sputum eosinophilia developed in all subjects. This result differs from the study of bronchial biopsies in prednisone-dependent asthma by WeNZEL et al. [9], where eosinophilia was chiefly absent,

Table 4. - Patient characteristics after 1 week of prednisone treatment

\begin{tabular}{|c|c|c|c|c|c|c|c|c|c|c|c|c|c|c|c|c|}
\hline \multirow[b]{2}{*}{$\begin{array}{l}\text { Subj. } \\
\text { No. }\end{array}$} & \multicolumn{5}{|c|}{ Clinical parameters } & \multicolumn{3}{|c|}{ Blood } & \multicolumn{8}{|c|}{ Sputum } \\
\hline & $\begin{array}{c}\text { Symp. } \\
\text { score }\end{array}$ & $\begin{array}{c}\text { PEF } \\
\text { L }\end{array}$ & $\begin{array}{l}\text { FEV1 } \\
\text { L (\%) }\end{array}$ & $\begin{array}{l}\text { Pred } \\
\text { mg. } \\
\text { day }^{-1}\end{array}$ & $\begin{array}{l}\text { Salb } \\
\mu \mathrm{g} \cdot \\
\text { day }^{-1}\end{array}$ & $\begin{array}{c}\mathrm{E} \\
\times 10^{6} \\
\mathrm{~L}^{-1}\end{array}$ & $\begin{array}{l}\text { ECP } \\
\mu \mathrm{g} \cdot \\
\mathrm{L}^{-1}\end{array}$ & $\begin{array}{l}\text { IL-5 } \\
\mathrm{pg} \cdot \\
\mathrm{mL}^{-1}\end{array}$ & $\begin{array}{c}\text { TCC } \\
\times 10^{6} \\
\mathrm{~mL}^{-1}\end{array}$ & $\begin{array}{l}\mathrm{E} \\
\%\end{array}$ & $\begin{array}{l}\mathrm{N} \\
\%\end{array}$ & $\begin{array}{l}\mathrm{L} \\
\%\end{array}$ & $\begin{array}{l}\mathrm{M} \\
\%\end{array}$ & $\begin{array}{l}\text { ECP } \\
\mu \mathrm{g} \cdot \\
\mathrm{L}^{-1}\end{array}$ & $\begin{array}{c}\mathrm{F} \\
\mu \mathrm{g} \cdot \\
\mathrm{L}^{-1}\end{array}$ & $\begin{array}{l}\text { IL-5 } \\
\text { pg. } \\
\mathrm{mL}^{-1}\end{array}$ \\
\hline 1 & 2 & 400 & $2.0(87)$ & 30 & 0 & 0.1 & 6.5 & UL & 4.3 & 0.8 & 70.0 & 0.5 & 28.2 & 624 & 1200 & 256 \\
\hline 2 & 9 & 400 & $2.8(93)$ & 30 & 400 & 0.1 & 13.0 & UL & 2.2 & 0.5 & 69.2 & 0.5 & 29.8 & 880 & 1280 & 80 \\
\hline 3 & 1 & 510 & $3.2(97)$ & 30 & 0 & 0.1 & 8.5 & 110 & 1.3 & 0 & 23.0 & 0.5 & 76.5 & 88 & 24600 & 46.4 \\
\hline 4 & 4 & 350 & $3.1(86)$ & 30 & 400 & 0.2 & 34.0 & UL & 2.5 & 0 & 4.7 & 0 & 95.0 & 696 & 6000 & 41.8 \\
\hline 5 & 9 & 200 & $1.1(48)$ & 50 & 800 & 0.0 & 8.3 & UL & 26.9 & 3.7 & 60.0 & 3.0 & 33.3 & 8400 & 9200 & UL \\
\hline 6 & 0 & 410 & $1.5(68)$ & 30 & 600 & 0.1 & 16.0 & 48 & 10.3 & 0 & 87.0 & 0 & 13.0 & 1184 & 4000 & 88 \\
\hline 7 & 0 & 500 & $3.0(75)$ & 30 & 0 & 0.2 & 7.9 & UL & 1.1 & 0 & 51.6 & 0 & 48.4 & 224 & 48800 & UL \\
\hline 8 & 0 & 360 & $3.7(86)$ & 30 & 0 & 0.1 & 13.0 & - & 1.9 & 0 & 56.5 & 0.5 & 43.0 & 704 & 11200 & UL \\
\hline
\end{tabular}

Abbreviations as in table 3 . 

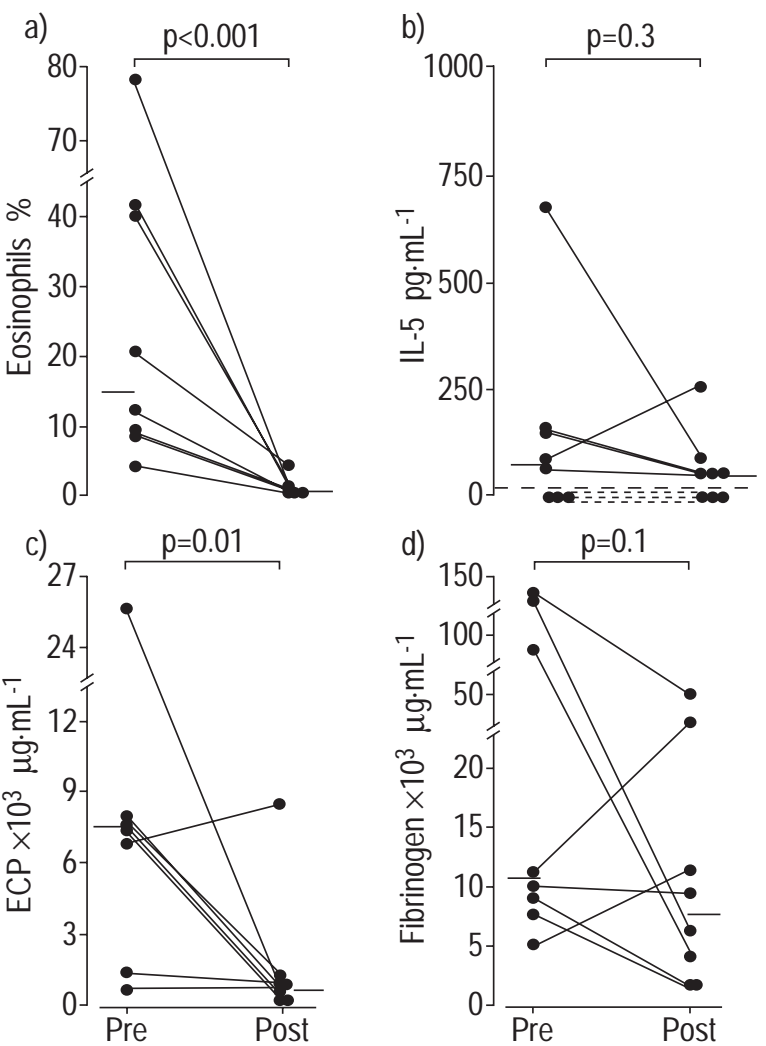

Fig. 2. - Individual values of a) sputum eosinophils, b) fluid-phase interleukin (IL)-5, c) eosinophil cationic protein (ECP); and d) fibrinogen during an exacerbation of asthma produced by a structured reduction of prednisone treatment, before (Pre) and after (Post) treatment with higher doses of prednisone. Horizontal bars are median values. The dashed line in (b) represents the limits of the detection of the IL-5 assay $\left(7.8 \mathrm{pg} \cdot \mathrm{mL}^{-1}\right)$.

possibly because the dose of prednisone that the patients were taking was enough to suppress the eosinophilia or because eosinophilia is apparent in sputum before bronchial mucosal eosinophilia. Examination of the effects of prednisone reduction on clinical parameters showed that these were exacerbated later than the sputum eosinophilia. This result raises the possibility that serial measurements of sputum eosinophils during prednisone reduction may be useful in optimizing the minimum dose of prednisone needed by such patients. The study also showed that the treatment of exacerbations with a higher dose of prednisone resulted in improvement in the clinical outcomes before the resolution of sputum eosinophilia, a result also reported in nonprednisone-dependent asthma [6].

The eosinophilic bronchitis was severe at the time of the exacerbation, as indicated by the pronounced sputum eosinophilia and elevated ECP and fibrinogen levels. This was despite treatment with the high dose of inhaled budesonide plus additional prednisone. The ECP and fibrinogen levels were higher than those previously reported in nonprednisone-dependent asthmatics with either stable [3] or severely exacerbated [6] asthma. The median levels of ECP and fibrinogen in the present study were 7,480 and $10,600 \mu \mathrm{g} \cdot \mathrm{L}^{-1}$ compared with 1,040 and $2,080 \mu \mathrm{g} \cdot \mathrm{L}^{-1}$ in stable asthma [3] and 1,920 and $6,045 \mu \mathrm{g} \cdot \mathrm{L}^{-1}$ in severely exacerbated asthma. The suppression of sputum eosinophilia and ECP by additional prednisone is in keeping with the effects of prednisone treatment in other studies $[6,20]$, while the lack of reduction of fibrinogen is not [6]. Fibrinogen was considered to be a marker of microvascular leakage but it may also be an index of local production by activated epithelial cells [20], which might take longer to be suppressed by prednisone treatment.

The sputum fluid-phase IL-5 measurements differed from those observed in the earlier study of the treatment of a severe exacerbation of asthma in nonprednisone-dependent patients [6], despite the use of the same processing procedure and IL-5 measurement kit. IL-5 could only be measured in five of the eight subjects and the medium level of $66.5 \mathrm{pg} \cdot \mathrm{mL}^{-1}$ was low compared with that of 160 $\mathrm{pg} \cdot \mathrm{mL}^{-1}$ in the earlier study, where sputum eosinophils and ECP were lower. The effect of the additional treatment with prednisone was also different. Sputum eosinophils and ECP fell within the normal range, while sputum IL-5 was not significantly reduced whereas, in the earlier study, there was simultaneous suppression of the eosinophilia, ECP and IL-5 and the changes in the IL-5 levels were strongly correlated with the changes in eosinophils and ECP $\left(\mathrm{r}_{\mathrm{s}}=0.9, \mathrm{p}<0.001\right.$ for both correlations). These differences in results may be methodological or may indicate that other cytokines (e.g. IL-3 or granulocyte-macrophage colony-stimulating factor) or chemokines (e.g. "regulated on activation, normal T-cell expressed and secreted" (RANTES) or eotaxin) are more important than IL-5 in the effect of prednisone in reducing sputum eosinophilia in prednisone-dependent asthmatics.

A mild sputum neutrophilia was also seen throughout the study, the degree of which was not altered by additional prednisone treatment. The role of sputum neutrophils in asthma has not been established. However, neutrophilia has been observed previously in the sputum of mild stable asthmatics [3, 21], in exacerbations [22] and in exacerbations associated with influenza [23] in bronchial biopsies and bronchoalveolar lavage of patients with prednisonedependent asthma [9] and in post mortem tissue from patients who had died from asthma [24, 25].

In conclusion, exacerbated prednisone-dependent asthma was associated with sputum eosinophilia and unusually high levels of eosinophil cationic protein and fibrinogen in the sputum. During prednisone reduction, the changes in sputum eosinophils preceded changes in symptoms and forced expiratory volume in one second, suggesting that changes in sputum eosinophils may be a useful measurement in clinical practice to help to determine the minimum regular dose of prednisone required to treat the asthma optimally. While eosinophils and eosinophil cationic protein responded to increased treatment with prednisone within 1 week of an exacerbation, fibrinogen and interleukin-5 levels seemed to respond to a lower degree than those reported in severe nonprednisone-dependent asthma [6]. The reason for these differences requires further investigation.

Acknowledgements. The authors wish to thank the patients who participated in this study, G. Gleich for his advice on interleukin-5 measurements and the interpretation of results, S. Weston for helping with cell counts, S. Evans for performing the fluid-phase measurements and Pharmacia Diagnostics AB, Uppsala, Sweden, for providing the eosinophil cationic protein (ECP) kits. 


\section{References} .Azzavi M, Bradley B, Jefferey PK, et al. Identification of activated $\mathrm{T}$ lymphocytes and eosinophils in bronchial biopsies in stable atopic asthma. Am Rev Respir Med 1990; 142: 1407-1413.

2. Bradley BL, Azzavi M, Jacobson M, et al. Eosinophils, T lymphocytes, mast cells, neutrophils, and macrophages in bronchial biopsies specimens from atopic subjects with asthma and normal control subjects and relationship to bronchial hyperresponsiveness. J Allergy Clin Immunol 1991; 88: 661-674.

3. Pizzichini E, Pizzichini MMM, Efthimiadis A, et al. Indices of airway inflammation in induced sputum: reproducibility and validity of cell and fluid phase measurements. Am J Respir Crit Care Med 1996; 154: 308317.

4. Dunnill MS. The pathology of asthma, with special reference to changes in the bronchial mucosa. J Clin Pathol 1960; 13: 27-33.

5. Bentley AM, Hamid Q, Robinson DS, et al. Prednisolone treatment in asthma: reduction in the number of eosinophils, T cells, tryptase-only positive mast cells, and modulation of IL-4, IL-5, and interferon-gamma gene expression within the bronchial mucosa. Am J Respir Crit Care Med 1996; 153: 551-556.

6. Pizzichini MMM, Pizzichini E, Clelland L, et al. Sputum in severe exacerbations of asthma: kinetics of inflammatory indices after prednisone treatment. Am J Respir Crit Care Med 1997; 155: 1501-1508.

7. Brown HM. Treatment of chronic asthma with prednislone: significance of eosinophils in the sputum. Lancet 1958; i: $1245-1247$.

8. Sher ER, Leung DYM, Surs W, et al. Steroid resistant asthma: cellular mechanism contributing to inadequate response to glucocorticosteroid therapy. $J$ Clin Invest 1994; 93: 33-39.

9. Wenzel SE, Szefler SJ, Leung DYM, Sloan SJ, Rex MD, Martin RJ. Bronchoscopic evaluation of severe asthma: persistent inflammation associated with high dose glucocorticoids. Am J Respir Crit Care Med 1997; 156: 737 743.

10. Paramesvaram K, Pizzichini MMM, Li D, Pizzichini E, Jeffery PK, Hargreave FE. Serial sputum cell counts in the management of chronic airflow limitation. Eur Respir $J$ 1998; 11: 1405-1408.

11. American Thoracic Society. Standardization of spirometry. 1987 Update. Am Rev Respir Dis 1987; 136: 1285-1298.

12. Crapo RO, Morris AH, Gardner RM. Reference spirometric values using techniques and equipment that meets
ATS recommendation. Am Rev Respir Dis 1981; 123: 659-694.

13. Juniper EF, Cockcroft DW, Hargreave FE. Histamine and methacholine inhalation tests: a laboratory tidal breathing protocol. 2nd Edn. Lund, Astra Draco, 1994.

14. Pepys J. Skin test in diagnosis. In: Gell PGH, Coombs RRA, Lachmann PJ, eds. Clinical Aspects of Immunology. 3rd Edn. Oxford, Blackwell Scientific Publications, 1975; pp. 55-80.

15. Pin I, Gibson PG, Kolendowicz R, Denburg JA, Hargreave FE, Dolovich J. Use of induced sputum cell counts to investigate airway inflammation in asthma. Thorax 1992; 47: 25-29.

16. Glantz SA, Slinker BK. Repeated measures. In: Glantz SA, Slinker BK, eds. Primer of Applied Regression and Analysis of Variance. New York, McGraw-Hill, 1990; pp. 381-420.

17. Pizzichini E, Pizzichini MMM, Efthimiadis A, Dolovich $\mathrm{J}$, Hargreave FE. Measuring airway inflammation in asthma: eosinophils and ECP in induced sputum compared with peripheral blood. J Allergy Clin Immunol 1997; 99: 539-544.

18. Horwitz RI, Viscoli CM, Clemens JD, Sadok RT. Developing improved observational methods for evaluating therapeutic effectiveness. Am J Med 1990; 89: 630-638.

19. Gauvreau GM, Doctor J, Watson RM, Jordana M, O'Byrne PM. Effects of inhaled budesonide on allergen-induced airway responses and airway inflammation. Am J Respir Crit Care Med 1996; 154: 1267-1271.

20. Haidaria PJ. Induction of fibrinogen biosynthesis and secretion from cultured pulmonary epithelial cells. Blood 1997; 89: 873-882.

21. Ronchi MC, Piragino C, Amendola M, Duranti R, Scano G. Role of sputum differential cell count in detaching airway inflammation in patients with chronic bronchial asthma or COPD. Thorax 1996; 51: 1000-1004.

22. Fahy JV, Kim KW, Lui J, Boushey HA. Prominent neutrophilic inflammation in sputum from subjects with asthma exacerbation. J Allergy Clin Immunol 1995; 95: 843-852.

23. Pizzichini MMM, Pizzichini E, Johnston S, et al. Asthma and natural colds: inflammatory indices in induced sputum. Am J Respir Crit Care Med 1998; 158: 1178-1184.

24. Azzavi M, Johnston PW, Majundar S, Kay AB, Jeffery PK. T-lymphocytes and activated eosinophils in airway mucosa in fatal asthma and cystic fibrosis. Am Rev Respir Dis 1992; 145: 1477-1482.

25. Sunjiv S, Crotty TB, Kephart GM, et al. Sudden onset fatal asthma: a distinct entity with few eosinophils and relatively more neutrophils in the airway submucosa. $\mathrm{Am}$ Rev Respir Dis 1993; 148: 713-719. 